\title{
Rare case of extranodal Rosai-Dorfman disease presenting as a middle cranial fossa tumour
}

\author{
Jennifer Yang, ${ }_{1}^{1}$ Robert Newbury, ${ }^{2}$ Denise Malicki, ${ }^{3}$ John Ross Crawford ${ }^{4}$
}

'Department of Neurosciences, University of California San Diego, La Jolla, California, USA 2Department of Pathology, Rady Children's Hospital, San Diego, California, USA

${ }^{3}$ Pathology, Rady Children's Hospital University of California San Diego, San Diego,

California, USA

${ }^{4}$ Neurosciences and Pediatrics, University of California San Diego, La Jolla, California, USA

Correspondence to Dr John Ross Crawford; jrcrawford@ucsd.edu

Accepted 11 February 2021

Check for updates

C) BMJ Publishing Group Limited 2021. No commercial re-use. See rights and permissions. Published by BMJ.

\begin{tabular}{l}
\hline To cite: Yang J, Newbury R, \\
Malicki D, et al. BMJ Case \\
Rep 2021;14:e241537. \\
doi:10.1136/bcr-2020- \\
241537 \\
\hline
\end{tabular}

\section{DESCRIPTION}

A 16-year-old previously healthy boy presented with a 7-year history of 'black out' spells. The patient reported that the episodes occurred one to two times in a month associated with dizziness and loss of consciousness without associated urinary or faecal incontinence. At times, he would have auditory hallucinations and brief lapses in memory. His neurological examination was normal. A CT of the head performed revealed a hyperdense right middle cranial fossa mass. MRI of the brain showed an enhancing, large dural-based mass in the right middle cranial fossa with an anterior dural tail and encasement of the cavernous and supraclinoid segments of the right internal carotid artery (figure 1). An MRI of the entire spine was normal. The patient underwent near-total resection, and frozen sections demonstrated dense fibrovascular connective tissue interspersed with clusters of small cells with high nuclear-to-cytoplasmic ratios with round or oval hyperchromatic nuclei as well as scattered lymphocytes and histiocytes (figure 2). Immunohistochemistry demonstrated negative epithelial membrane antigen. S100 and CD68 positive histiocytes were identified that were CD1a negative, and CD20 and CD3 positive lymphocytes were also present. Together, this constellation of findings

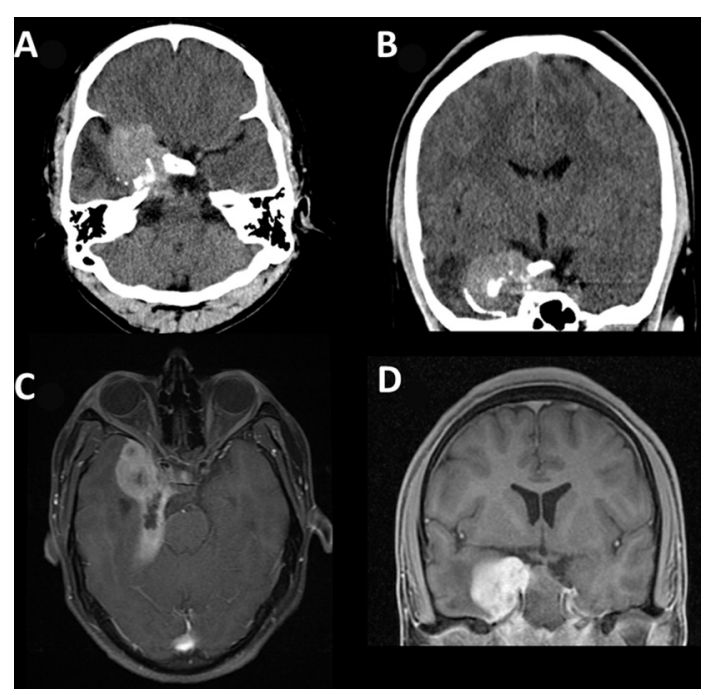

Figure 1 CT head shows a hyperdense, extra-axial mass in the right middle cranial fossa (A) with partial calcification (B). MRI brain T1 post-contrast study shows an enhancing mass with an anterior dural tail extending along the right petrous bone, encasing the cavernous and parasellar region $(\mathrm{C})$ and causing mild mass effect on the lateral aspect of the right midbrain and right mesial temporal lobe (D).

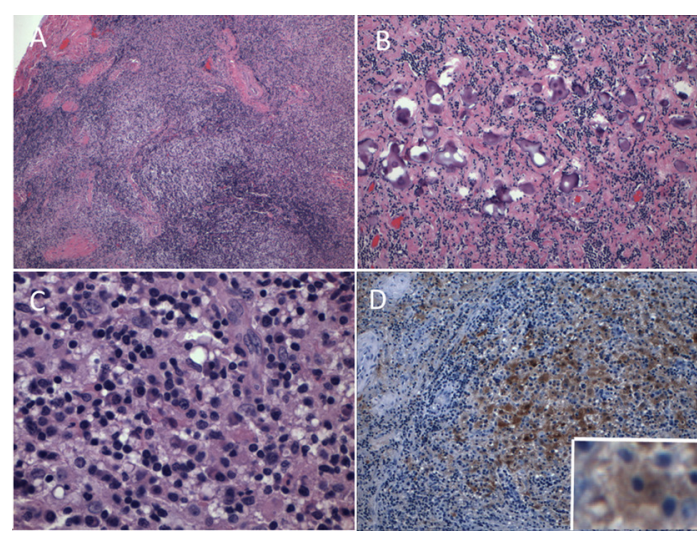

Figure 2 Histopathology reveals the following results: (A) H\&E 40x: clusters of lymphocytes and histiocytes; (B) H\&E 100x: whorls of dense, paucicellular connective tissue with occasional spindle cells surrounded by chronic inflammatory cell infiltrate; (C) 200x: histiocytes with clear cytoplasm and dense central nuclei; and (D) S100 immunohistochemistry reveals positive staining of histiocytes and rare emperipolesis (inset).

was most consistent with the diagnosis of RosaiDorfman disease. ${ }^{1}$ The patient had good clinical recovery after surgery and remains disease free for 6 years following diagnosis.

Rosai-Dorfman disease is a non-Langerhans cell histiocytic condition more frequently seen in children and young adults that typically presents with fever and painless cervical lymphadenopathy with some association with hypergammaglobulinaemia. ${ }^{2}$ Recent genomic studies have demonstrated mutations involving the mitogen-activated protein kinase pathway and various other intracellular transcriptional and cell cycle regulation mechanisms. ${ }^{1}$ Isolated extranodal disease is rare, though central nervous system involvement including dural, parenchymal and spinal lesions has been reported and oftentimes mimics meningioma on

\section{Learning points}

- Rosai-Dorfman disease is a histiocytic condition that can present with isolated extranodal intracranial involvement mimicking meningioma on neuroimaging.

- Histological hallmarks are S100 and CD68 positive histiocytes that are CD1a negative and the presence of emperipolesis.

- Prognosis is generally good for isolated cases following surgical resection. 
neuroimaging. ${ }^{3-5}$ The management of isolated extranodal RosaiDorfman disease is generally surgical resection and carries an overall good prognosis. $^{2}$

Contributors Dr JY, Dr RN, Dr DM and Dr JRC were responsible for the design and writing of the manuscript.

Funding The authors have not declared a specific grant for this research from any funding agency in the public, commercial or not-for-profit sectors.

Competing interests None declared.

Patient consent for publication Obtained.

Provenance and peer review Not commissioned; externally peer reviewed.

\section{REFERENCES}

1 Bruce-Brand C, Schneider JW, Schubert P. Rosai-Dorfman disease: an overview. J Clin Pathol 2020:73:697-705.

2 Abla 0 , Jacobsen E, Picarsic J, et al. Consensus recommendations for the diagnosis and clinical management of Rosai-Dorfman-Destombes disease. Blood 2018;131:2877-90.

3 Hong CS, Starke RM, Hays MA, et al. Redefining the prevalence of dural involvement in Rosai-Dorfman disease of the central nervous system. World Neurosurg 2016;90:702. e13-702.e20.

4 Prayson RA, Rowe JJ. Dural-based Rosai-Dorfman disease: differential diagnostic considerations. J Clin Neurosci 2014;21:1872-3.

5 Sandoval-Sus JD, Sandoval-Leon AC, Chapman JR, et al. Rosai-Dorfman disease of the central nervous system. Medicine 2014;93:165-75.

Copyright 2021 BMJ Publishing Group. All rights reserved. For permission to reuse any of this content visit

https://www.bmj.com/company/products-services/rights-and-licensing/permissions/

BMJ Case Report Fellows may re-use this article for personal use and teaching without any further permission.

Become a Fellow of BMJ Case Reports today and you can:

- Submit as many cases as you like

- Enjoy fast sympathetic peer review and rapid publication of accepted articles

- Access all the published articles

Re-use any of the published material for personal use and teaching without further permission

Customer Service

If you have any further queries about your subscription, please contact our customer services team on +44 (0) 2071111105 or via email at support@bmj.com.

Visit casereports.bmj.com for more articles like this and to become a Fellow 